\title{
The important role of Type A Hospital in efforts to reduce the covid-19 cluster by improving the dimension of service quality in building satisfaction and loyalty of covid-19 patients in Surabaya
}

\author{
Belina Pangemanan ${ }^{1}$, Cindy Walewangko², Marcella Mitzy ${ }^{3}$, Amelia $^{4}$ * \\ a bn80039@student.uph.edu \\ ${ }^{a}$ Management, Universitas Pelita Harapan Surabaya Campus \\ Jl. Ahmad Yani no. 288, Surabaya, 60234
}

\begin{abstract}
COVID-19 in Surabaya has reached 20,832 cases. Of these, 19,270 people have recovered, and 1,313 people have died and 249 people are being treated on the Surabaya COVID-19 Response website. In addition, the Surabaya City Government is also still working continuously in the vaccination process which until now recorded 34,869 people have been vaccinated in the first stage. Therefore, this study was conducted to know the development of health services hospital type A referral COVID-19 in Surabaya.

The purpose of this study is to evaluate and analyze behavioral intentions of COVID-19 survivors at COVID-19 referral type A hospitals in Surabaya. Based on the purpose of the study, the expected benefit of this study is to increase knowledge in the field of management, in this case related to variables Technical Quality, Infrastructural Quality, Interactional Quality, Personnel Quality, Social Support Quality, Patient Satisfaction, and Behavioral Intention.

This research is a causal study with quantitative research methods. The data analysis process uses the process of validity test analysis, reliability test, classical assumption test using SPSS 22.0 software. The data collection in this study was conducted by spreading questionnaires through google form to more than 140 respondents with characteristics who areCOVID-19 survivors at COVID-19 referral type A Hospital in Surabaya.
\end{abstract}

Keywords: Health Service, Service Quality 


\section{Introduction}

The community is being alarmed by the COVID-19 virus that was underinfected by a Japanese citizen who was infected in January 2020. From then on, the government is more concerned about who has been in contact with the Japanese national. However, the government was late in conducting searches so that COVID-19 has spread rapidly throughout Indonesia until January 2021 has taken the lives of approximately 30,000 people from approximately 1 million Indonesians exposed to the coronavirus. This causes the need for the Hospital industry to increase rapidly whether it is COVID-19 patients or patients who experience other diseases accompanied by procedures that are added to hospital admission that has been standardized for all patients to take the COVID-19 test whatever the symptoms of the disease. Hospital is one of the health care industry that performs complete individual health services that provide inpatient, outpatient, and emergency services. From these services, the Hospital also conducts several lines of service including medical services, medical support services, treatment services, rehabilitation services, prevention and health improvement, as well as a place for education and or medical and medical training, as a place of research and development of health science and technology and also available services to avoid risks and health problems (medical check-up).

With these existing services, hospitals can prefer to focus on several services. With the increasing need for the use of hospitals, the hospital industry in Indonesia is experiencing a development in the number of hospitals that continue to increase over time. Especially with the positive cases of COVID-19 that continues to grow, the government is also preparing many COVID-19 standby hospitals. Indonesia has several Types of Hospitals recognized by the Indonesian government, the Hospitals are Type A, Type B, Type C, and Type D Hospitals. In this study, the object of the study was Type A Hospital. Type A Hospital itself is a Hospital that according to its name is a Hospital with central health services. Which means, this Type A Hospital is the highest referral hospital (top referral hospital) for BPJS participants and other patients. COVID-19 in the city of Surabaya has reached 20,832 cases when this study occurred. Of these, 19,270 people have recovered, and 1,313 people have died and 249 people are being treated on the Surabaya COVID-19 Response website. In addition, the Surabaya City Government is also still working continuously in the vaccination process which until now recorded 34,869 people have been vaccinated in the first stage. With this, the city of Surabaya has the status of an orange zone that makes the city of Surabaya still have to keep trying to expand tracing efforts. Therefore, this research was conducted to be able to find out the development of hospital health services type A referral covid in Surabaya.

Table 1. List of COVID Referral Type A Hospitals in Surabaya

\begin{tabular}{|l|l|l|l|}
\hline \multicolumn{4}{|c|}{ Rumah Sakit Tipe A Rujukan COVID-19 di Surabaya } \\
\hline No. & Nama Rumah Sakit & Tahun Berdiri & Kepemilikan \\
\hline 1. & RSUD Dr Soetomo & 1938 & Pemerintah \\
\hline 2. & RS Dr Ramelan & 1950 & Kementerian pertahanan \\
\hline
\end{tabular}

Source: www.google.com

As a hospital that is at the top level that wants to continue to survive and grow in the treatment of COVID-19 Type A patients in Surabaya, it is necessary to improve behavioral intentions. Therefore, it is important to know the variables that affect the patient's intentions so that patients can re-examine at these two hospitals. In this study, the factors studied were technical quality, insfrastructural quality, interactional quality, personnel quality, and social support quality in influencing behavioral intention through customer satisfaction.

\section{1-1 Problem Formula}

The problem formulation of this study is whether technical quality, infrastructural quality, interactional quality, personnel quality, and social support quality have a significant influence on patient satisfaction, and 
whether patient satisfaction has a significant influence on behavioral intentions in patients 2 COVID-19 Referral Hospital Type A in Surabaya.

\section{1-2 Research Objectives}

Based on the background description and problem formulation, it is expected that the purpose of this study is to find out and analyze the significant influence of technical quality, infrastructural quality, interactional quality, personnel quality, and social support quality on patient satisfaction, as well as the significant influence of patient satisfaction on behavioral intentions in patients 2 COVID-19 Type A Referral Hospital in Surabaya.

\section{1-3 Benefits of Research}

The results of this study are expected to provide the following theoretical benefits: (1) This study can be useful as a reference for other researchers who want to research behavioural intention, patient satisfaction, technical quality, infrastructural quality, interactional quality, personnel quality, and social support quality; (2) This research can be useful as a reference source for other students who want to make similar research; (3) Add insight into the various problems that occur in COVID-19 services in Surabaya. And can provide empirical benefits from this study which includes: (1) This research can be useful for the Surabaya City Government who want to know from the 2 COVID-19 Type A Referral Hospitals in Surabaya that are most frequently visited and have the best service; (2) This research can also be useful as input for companies engaged in the healthcare industry, either going to or have run a healthcare business, to increase the number of customers and attract consumers. (3) Each of the 2 COVID-19 Type A Referral Hospitals in Surabaya can find out what are the complaints of COVID-19 patients in the service of each of the 2 COVID-19 Type A Referral Hospitals in Surabaya.

\section{Literature and theoretical foundations of research}

Based on the formulation of the problems that have been described in the previous chapter, namely whether technical quality, infrastructural quality, interactional quality, personnel quality, and social support quality have a significant influence on patient satisfaction, and whether patient satisfaction has a significant influence on behavioral intentions, the following is stated the formulation of the library about the dimensions of technical quality, infrastructural quality, interactional quality, personnel qual ity, social support quality, patient satisfaction, and behavioral intention.

\section{2-1 Technical Quality}

Technical quality is one of the factors of service quality that is very influential in patient satisfaction. Technical quality has proven to be the best determinant of consumer satisfaction when in the service sector (Khaliq, 2019). Ahmed et al. (2010) examined the relationship of patient satisfaction with technical quality. The result is patient satisfaction is closely related to technical quality. Chou (2014) also found that technical quality is one element of service quality that directly affects patient satisfaction. Thus, technical quality is an important antecedent of patient satisfaction (Cronin \& Taylor, 1992).

Based on the above explanation, the following hypothesis can be concluded:

H1: Technical Quality has a significant effect on Patient Satisfaction.

With 4 indicators of variable technical quality, namely:

1. Doctors at Type B Hospitals conduct a thorough examination of the disease

2. Doctors at Type B Hospitals provide treatment to patients with critical symptoms

3. The patient does not experience complications due to hospital treatment accordingly.

4. The patient recovers after receiving good treatment from the Hospital. 


\section{2-2 Infrastructural Quality}

According to Padma, et al. (2010), there is a significant impact between infrastructural quality and patient satisfaction. Chen et al. (2014) also obtained the results that infrastructural quality has a positive effect on patient satisfaction for airport customers. Likewise with Baker (2013), who obtained research results from the aviation industry that infrastructural quality affects patient satisfaction. So according to Chuang and Lin (2013), organizations that have valuable infrastructural qualities and cannot be replaced, can be a sustainable force for organizations to get patient satisfaction.

Based on some of the findings presented above, a hypothesis can be concluded as follows:

H2: Infrastructural Quality has a significant effect on Patient Satisfaction

With 4 indicators of variable infrastructural quality, namely:

1. Patients feel the hospital room owned by Type A Hospital is maintained cleanliness

2. Patients are provided with medical personnel who serve on time at Type A Hospitals

3. Patients are provided with complete medicines on time at Type A Hospital in Surabaya

4. Patients get adequate quantity of food in Type A Hospitals

\section{2-3 Interactional Quality}

According to Oliver (2010), consumers tend to experience dissatisfaction when receiving poor treatment from a company or organization. Consumers tend to immediately think negatively when receiving unfair results from employees of a company. Therefore, the influence of interactional quality on patient satisfaction is very important. According to Martinez, et al. (2006) also, consumers will feel satisfaction when getting good quality treatment, which results in the discovery that interactional quality positively affects patient satisfaction. According to Namkung and Jang (2009), interactional quality has a significant effect on patient satisfaction.

Based on the findings above, a hypothesis can be concluded as follows:

H3: Interactional Quality has a significant effect on Patient Satisfaction

With 4 indicators of variable interactional quality, namely:

1. Patients feel given special attention by medical personnel of Type A Hospital (examples of additional services outside of operating hours)

2. Patients are provided with clear information regarding the results of the diagnosis of the disease to be treated by Type A Hospital

3. Patients are provided with clear information related to all COVID-19 treatment processes in Type A Hospitals

4. Patients are provided with clear information regarding the finances that are necessary during the treatment process

\section{2-4 Personnel Quality}

According to Farooq, et al. (2018), higher personnel quality of a service will significantly increase patient satisfaction. Likewise, the discovery of Ali et al. (2015) which suggests that good personnel quality has a significant influence on patient satisfaction. Saha and Theingi (2009) also found that personnel quality is very important in bringing up patient satisfaction of a company or organization. So Nadiri et al. (2008) found that personnel quality positively contributes to patient satisfaction.

Based on the findings above, it can be concluded a hypothesis as follows: 
H5: Personnel Quality has a significant effect on Patient Satisfaction

With 4 indicators of variable personnel quality, namely:

1. Patients are provided by doctors who have the expertise to provide effective care for patients by Type A Hospitals

2. Patients are provided by a medical team that has the competence to provide appropriate medical care at Type A Hospitals

3. Patients believe in the credibility of administrative services of Type A Hospitals

4. Patients believe that Type A Hospital provides services as promised

\section{2-5 Social Support Quality}

According to Zhu, et al. (2016), social support quality has a positive influence on patient satisfaction. Consumers will appreciate a company or organization that has social support with good quality. Mendonca et al. (2015) also supports the above statement because it gets results that social support quality also has a significant influence in the development of patient satisfaction. Bentley et al. (2016) also found that social support quality can increase patient satisfaction and affect consumers in treatment to organizations or companies.

From some of the discussions above, a hypothesis can be concluded as follows:

H6: Social Support Quality has a significant impact on Patient Satisfaction

With 4 indicators of the Social Support Quality variable, namely:

1. Patients feel that Type A Hospitals have a good reputation

2. Patients feel that Type A Hospitals perform treatment according to the code of ethics

3. Patients are provided with BPJS services by Type A Hospitals

4. Patients feel fair by the treatment of nurses from Type A Hospitals just like other patients

\section{2-6 Patient Satisfaction}

According to Han and Ryu (2009), patient satisfaction has a significant effect on customer behavioural intentions. Liang and Zhang (2012) also concluded that patient satisfaction is positively related to behavioural intentions in increasing consumers in order to be closely related to companies and organizations. Likewise with Shahid et al. (2018) who presented a study with the results of patient satisfaction has a significant effect on the behavioural intention of customers to an organization or company. So in previous research put forward by Lin and Hsieh (2006) that patient satisfaction is positively associated with consumer behavioural intentions.

Based on the explanation above, a hypothesis can be concluded as follows:

H7: Customer Satisfaction has a significant effect on Behavioral Intention.

With 5 indicators of variable patient satisfaction, namely:

1. Patients feel satisfaction with the procedure services provided by Type A Hospitals

2. Patients feel satisfaction with medical care by medical staff of Type A Hospital

3. Patients feel satisfaction with the services provided by Type A Hospital staff

4. The patient feels satisfaction with the conformity of the amount of costs incurred for treatment with the medical care received

5. Patients feel satisfaction with the comfortable atmosphere of Type A Hospital 


\section{2-7 Behavioral Intention}

According to Kotler (2014) behavioural intention is a condition where customers have an intention or loyal attitude to the brand, product and company, and willingly tell their superiority to others. For Deaux and Snyder (2018), the definition of behavioural intention is something that makes a person believe what they can do in a given situation. According to Mowen and Minor (2012), behavioural intention can also be defined as the desire of consumers to behave in a certain way in order to own, discard and use products / services. However, according to Saha and Theingi (2009), behavioural intention is defined as a possibility of a customer to perform a certain behavior such as positive word-of-mouth about a service provider to others, having the intention of buying back and loyalty to the service provider provider.

With 3 indicators of variable behavioral intention, namely:

1. Patients will spread positive things about Type A Hospital to existing friends

2. The patient wishes to return to the same Type A Hospital for re-treatment

3. Patients want to recommend this Type A Hospital to relatives to treat various diseases in Type A Hospitals

\subsection{Empirical background of the research}

The first reference to this study is a previous study conducted by Swain and Kar (2018). Swain and Kar (2018) conducted the study by discussing what are the impacts of technical quality, procedural quality, infrastructural quality, interactional quality, personnel quality, and social support quality to behavioural intentions with moderation by Patient Satisfaction which is overall perceived service quality in the context of hospital services. The purpose of this study was to explore the dimensions of perceived service quality from hospitals and to develop a framework concept that demonstrates the relationship between service quality, patient satisfaction, and behaviour intention. Swain and Kar (2018) conducted qualitative research based on literature with the existing SERVQUAL scale divided into 2 large sections, the first part is about the dimensions of service quality, especially in health settings and the second part is about the relationship between quality of service, customer satisfaction and intention to behave with the number of literature samples are 40 and 15 journals that are considered appropriate with the criteria that are the availability of full access by researchers, the appearance of the terms hospital service quality /health care and/or consumer satisfaction in the title, abstract, and keywords, and relevance to this journal's research.

\section{Research Methodology \\ 3-1 Types of Research}

This type of research is causal research because it is used to explain the causal relationship between the variables in the research model that has been presented. The research method used in this study is a quantitative method based on numerical information and quantities usually associated with statistical analyses (Stokes, 2007). While the data analysis process uses validity test methods, reliability tests, klasi assumption tests, and regression tests with SPSS 22.0 software.

\section{3-2 Population and Sample}

The population used in this study is the entire population of Surabaya who are COVID-19 survivors at Type A Hospital in Surabaya. The sampling technique used is non-probability sampling with purposive sampling method because it is not known the exact number of Bank BCA customers. The characteristics of the respondents who were determined were men and women, aged 18-60 years, domiciled in Surabaya, had contracted the COVID-19 virus and had successfully recovered, had made transactions and used inpatient and outpatient services for the treatment of COVID-19 disease at Type B Hospital in Surabaya. Ferdinand (2002) has the following sample size guidelines: (1) 100-200 samples for Maximum Likelihood Estimation; (2) depends on the number of parameters estimated. The guideline is 5-10 times the number of parameters estimated; (3) depends on the number of indicators used in all latent variables. The number of samples is an indicator multiplied by 5 to 10 . So based on Ferdinand's theory (2002) it can be known that the number of 
samples of this study as many as 75 to 150 respondents because of this research indicator as many as 15 .

\section{3-4 Data collection method}

The data used in this study is primary data that is data collected from respondents' answers through questionnaires in the form of Google Form. The questionnaire will be distributed through the authors' social media and with the help of patient data by the Hospital. The questionnaire will consist of two parts: (1) questions of respondents' characteristics and (2) statements about the object of the study. These statements will use the Likert Scale 5 scale.

\section{3-4 Data Analysis Methods}

The study used SPSS version 22.0 for statistical testing. Such tests include validity and reliability tests, classical assumption tests, and regression tests.

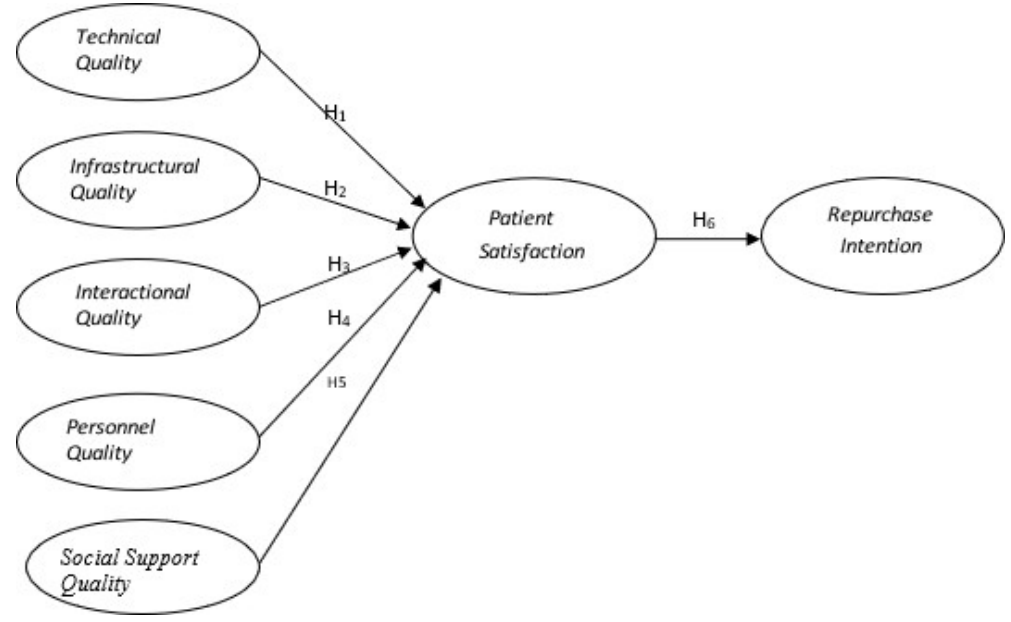

Fig. 2 Conceptual model of research

\section{Research findings}

4-1 Research validation

Table 2. Validity Test Results

\begin{tabular}{|c|c|c|c|c|}
\hline Variable & Indicators & Component & $\begin{array}{c}\text { Critical } \\
\text { Value }\end{array}$ & Information \\
\hline \multirow{4}{*}{$\begin{array}{l}\text { Technical } \\
\text { Quality } \\
\text { (TQ) }\end{array}$} & TQ1 & 0,453 & 0,252 & Valid \\
\hline & TQ2 & 0,716 & 0,252 & Valid \\
\hline & TQ3 & 0,511 & 0,252 & Valid \\
\hline & TQ4 & 0,715 & 0,252 & Valid \\
\hline \multirow{5}{*}{$\begin{array}{c}\text { Infrastructural } \\
\text { Quality } \\
\text { (IaQ) }\end{array}$} & $\mathrm{IaQ1}$ & 0,455 & 0,252 & Valid \\
\hline & $\mathrm{IaQ2}$ & 0,63 & 0,252 & Valid \\
\hline & IaQ3 & 0,668 & 0,252 & Valid \\
\hline & $\mathrm{IaQ4}$ & 0,701 & 0,252 & Valid \\
\hline & IeQ1 & 0,778 & 0,252 & Valid \\
\hline
\end{tabular}




\begin{tabular}{|c|c|c|c|c|}
\hline \multirow{3}{*}{$\begin{array}{l}\text { Interactional } \\
\text { Quality (IeQ) }\end{array}$} & IeQ2 & 0,646 & 0,252 & Valid \\
\hline & IeQ3 & 0,661 & 0,252 & Valid \\
\hline & IeQ4 & 0,707 & 0,252 & Valid \\
\hline \multirow{4}{*}{$\begin{array}{c}\text { Personnel } \\
\text { Quality } \\
\text { (PQ) }\end{array}$} & PQ1 & 0,535 & 0,252 & Valid \\
\hline & PQ2 & 0,488 & 0,252 & Valid \\
\hline & PQ3 & 0,63 & 0,252 & Valid \\
\hline & PQ4 & 0,65 & 0,252 & Valid \\
\hline \multirow{5}{*}{$\begin{array}{l}\text { Social } \\
\text { Support } \\
\text { Quality } \\
\text { (SSQ) }\end{array}$} & SSQ1 & 0,582 & 0,252 & Valid \\
\hline & SSQ2 & 0,552 & 0,252 & Valid \\
\hline & SSQ3 & 0,47 & 0,252 & Valid \\
\hline & SSQ4 & 0,788 & 0,252 & Valid \\
\hline & PS1 & 0,466 & 0,252 & Valid \\
\hline
\end{tabular}

Source: Processed data, 2021

Based on the tests in the table above, it is known that the pearson moment value of all variable indicators is greater than 0.166 . Therefore, it can be concluded that all research indicators are valid.

\section{4-2 Research reliability}

Table 3. Reliability Test Results

\begin{tabular}{|c|c|c|c|c|c|}
\hline No. & Variable & $\begin{array}{c}\text { Cronbach Alpha } \\
\text { Based on } \\
\text { Standardized } \\
\text { Items }\end{array}$ & $\begin{array}{c}\text { Critical } \\
\text { Number }\end{array}$ & $\begin{array}{l}\text { N of } \\
\text { Items }\end{array}$ & Description \\
\hline 1. & Technical Quality & 0,709 & 0,6 & 4 & Reliable \\
\hline 2. & $\begin{array}{c}\text { Infrastructural } \\
\text { Quality }\end{array}$ & 0,729 & 0,6 & 4 & Reliable \\
\hline 3. & Interactional Quality & 0,816 & 0,6 & 4 & Reliable \\
\hline 4. & Personnel Quality & 0,678 & 0,6 & 4 & Reliable \\
\hline 5. & $\begin{array}{c}\text { Social Support } \\
\text { Quality }\end{array}$ & 0,708 & 0,6 & 4 & Reliable \\
\hline 6. & Patient Satisfaction & 0,612 & 0,6 & 5 & Reliable \\
\hline 7. & Behavioral Intention & 0,661 & 0,6 & 3 & Reliable \\
\hline
\end{tabular}

Source: Processed data, 2021

\section{4-2 Test results of research hypotheses}

In this chapter will be presented about the results of data processing using SPSS 22.0 software. This study used 6 hypotheses, namely Technical Quality, Infrastructural Quality, Interactional Quality, Personnel Quality, and Social Support Quality, which has a significant effect on Patient Satisfaction and Patient Satisfaction has a significant effect on Behavioral Intention. In looking at the results of hypothesis testing, this study uses the F \& T Test. The hypothesis model used in this F Test is as follows: H0 : b1 $=b 2=b 3=b 4=$ $\mathrm{b} 5=0$, meaning that simultaneously there is no influence and significance of the free variable (PS) to the 
bound variable $(\mathrm{BI})$; free variables (TQ, IaQ, IeQ, PeQ, SSQ) against bound variables (PS). H1: $\mathrm{b} 1 \neq \mathrm{b} 2 \neq \mathrm{b} 3$ $\neq \mathrm{b} 4 \neq \mathrm{b} 5 \neq 0$, meaning that simultaneously there is an influence and significance of free variables (PS) to bound variables $(\mathrm{BI})$; free variables (TQ, IaQ, IeQ, PeQ, SSQ) against bound variables (PS). Test criterion F is as follows: If the significance of the $>0.05$ then the hypothesis is rejected. If the significance $\leq 0.05$ then the hypothesis is accepted.

Tabel 4. F-Test Results

\begin{tabular}{|l|l|l|l|}
\hline Variable & Sig. & Standard & Information \\
\hline TQ,PrQ,IaQ,IeQ,PeQ,SSQ*PS & 0.00 & 0.05 & Hypotheses Accepted \\
\hline PS*BI & 0.00 & 0.05 & Hypotheses Accepted \\
\hline
\end{tabular}

Source: Processed data, 2021

Based on the ANOVA or F test in the table above, the significance (TQ, IaQ, IeQ, PeQ, SSQ *PS) is 0.00. Based on the hypothesis testing criteria if the significance of the $\leqslant 0.05$, then the hypothesis is accepted, meaning that the variables are free Technical Quality, Infrastructural Quality, Interactional Quality, Personnel Quality, and Social Support Quality simultaneously significantly affect Patient Satisfaction. Based on the ANOVA or F test in the table above, the significance (PS*BI) is 0.00 . Based on the hypothesis testing criteria if the significance of the $\leqslant 0.05$, then the hypothesis is accepted, meaning that the patient satisfaction (PS) free variable simultaneously has a significant effect on behavioral intention (BI).

The $\mathrm{T}$ test is used to determine whether there is a meaningful relationship or influence (significant) between the technical quality, infrastructural quality, interactional quality, personnel quality, and social support quality variables partially to the patient satisfaction (PS) bound variables in the first test, then between patient satisfaction (PS) free variables against variables bound by behavioral intention (BI) in the second test.

Tabel 4. T-Test Results

\begin{tabular}{|l|l|l|l|l|}
\hline No. & Variabel & Sig & Standard & Information \\
\hline 1 & TQ *PS &, 008 & 0.05 & Hypotheses Accepted \\
\hline 2 & IaQ *PS &, 050 & 0.05 & Hypotheses Accepted \\
\hline 3 & IeQ *PS &, 083 & 0.05 & Hypotheses Denied \\
\hline 4 & PQ *PS &, 020 & 0.05 & Hypotheses Accepted \\
\hline 5 & SSQ *PS &, 117 & 0.05 & Hypotheses Denied \\
\hline 6 & PS *BI & 0.016 & 0.05 & Hypotheses Accepted \\
\hline
\end{tabular}

Source: Processed data, 2021

Then the test criteria are as follows:

If the significance $>0.05$, then the hypothesis is rejected.

If the significance $\leqslant 0.05$, then the hypothesis is accepted.

Based on the table above, it can be known that:

1. Variabel Technical Quality (TQ)

The value of the significance of the variable TQ is 0.008 , then the significance $<$ standard $(0.008<0.05)$. So it can be concluded that TQ has an effect $(0.008<0.05)$ alone on Patient Satisfaction in COVID-19 Survivors who have been treated at Type B Hospitals in Surabaya.

2. Variabel Infrastructural Quality (IaQ)

The value of the significance of the variable IaQ is 0.050 , then the significance $<$ standard $(0.050<0.05)$. So it can be concluded that IaQ has an effect $(0.050<0.05)$ alone on Patient Satisfaction in COVID-19 Survivors who have been treated at Type B Hospitals in Surabaya. 


\section{Variabel Interactional Quality (IeQ)}

The value of the significance of the variable IeQ is 0.083 , then the significance $>$ standard $(0.083>0.05)$. So it can be concluded that IeQ does not have an effect $(0.083>0.05)$ alone on Patient Satisfaction in COVID-19 Survivors who have been treated at Type B Hospitals in Surabaya.

4. $\quad$ Variabel Personnel Quality (PeQ)

The value of the significance of the variable PeQ is 0.020 , then the significance $<$ standard $(0.020<0.05)$. So it can be concluded that $\mathrm{PeQ}$ has an effect $(0.020<0.05)$ alone on Patient Satisfaction in COVID-19 Survivors who have been treated at Type B Hospitals in Surabaya.

5. Variabel Social Support Quality (SSQ)

The value of the significance of the variable SSQ is 0.117 , then the significance $>$ standard $(0.117>0.05)$. So it can be concluded that SSQ does not have an effect $(0.117>0.05)$ alone on Patient Satisfaction in COVID-19 Survivors who have been treated at Type B Hospitals in Surabaya.

6. $\quad$ Variabel Patient Satisfaction (PS)

The value of the significance of the variable PS is 0.016 , then the significance $<$ standard $(0.016<0.05)$. So it can be concluded that PS has an effect $(0.016<0.05)$ alone on Behavioral Intention in COVID-19 Survivors who have been treated at Type B Hospitals in Surabaya.

\section{Discussion and Conclussion}

In this chapter will be explained about conclusions, implications, and recommendations based on the results of data processing, discussions related to the formulation of the problems presented in this study. This study used variables technical quality, infrastructural quality, interactional quality, personnel quality, social support quality, patient satisfaction, and behavioral intention. Through the results of the conclusions, the implications and recommendations are expected to be a consideration for the relevant parties in connection with the object of this research, namely the Hospital industry and the Health sectors and government sectors. The consideration material is expected to also provide a benchmark to the relevant parties to carry out policy development in order to be better. The explanation of the conclusions of this study will be divided into research results, implications, and recommendations.

\section{Results of the study:}

1. Technical Quality is significantly affected by Patient Satisfaction.

2. Infrastructural Quality is significantly affected by Patient Satisfaction.

3. Interactional Quality affected by Patient Satisfaction not significantly

4. Personnel Quality is significantly affected by Patient Satisfaction.

5. Social Support Quality affected by Patient Satisfaction not significantly.

6. Patient Satisfaction is significantly affected by Behavioral Intention.

\section{Theoretical Implications:}

This research theoretically contributes to the development of behavioral intention theory in general and specifically the development of behavioral intention theory from a higher education perspective. Theories that have been developed through previous research are retested to see their relevance to the times and to obtain new evidence that can support and enrich or contradict existing theories.

The study found a causal relationship between variables of Technical Quality, Infrastructural Quality, Interactional Quality, Personnel Quality, and Social Support Quality to Patient Satisfaction and Behavioral Intention. The results of this study provide further answers to research from Swain and Kar (2018) which states that technical quality, procedural quality, infrastructural quality, interactional quality, personnel quality, and social support quality are significantly related to Patient Satisfaction and Patient Satisfaction significantly related to Behavioral Intention which is overall perceived service quality in the context of hospital services. And the results of this study also provide different answers to research from Swain and Kar (2018) where 
there are two hypotheses that are rejected, namely the Interactional Quality hypothesis has a significant effect on Patient Satisfaction and the Social Support Quality hypothesis has a significant effect on Patient Satisfaction. This is because in the current fact, the interaction of medical personnel and patients is limited by the new Standard Operation Procedure in the regulation published by the Ministry of Health, namely the regulation on Social Distancing. Therefore, variable Interactional Quality is not so necessary at this time. The second is about the variable Social Support Quality, looking at the fact that it is happening at this time, patients no longer ignore the reputation of the Hospital, due to the increasing bed occupation rate. So, the social support quality variable is not so necessary at this time.

\section{Practical Implications:}

This research in addition to making a theoretical contribution, this research also makes practical contributions that can be applied in the development of the Health sector in the COVID-19 pandemic. The results of this study can make the following practical contributions:

Variables of Technical Quality, Infrastructural Quality, and Personnel Quality, have a significant influence in improving Patient Satisfaction and Patient Satisfaction has a significant influence in improving Behavioral Intention. The practical implications that can be done to behavioral intentions in accordance with the dimensions of behavioral intentions are as follows:

1. The company can increase the behavioral intention variable then it must be increased in patient satisfaction, but the variable is an affection variable where the variable is a variable that is difficult to deal with, then the most influential and the largest in patient satisfaction with the highest regression coefficient attached to the attachment is 0.374 is the infrastructural quality variable.

2. In improving Infrastructural Quality, the Hospital needs to improve starting from the highest indicator on the validity value of variable infrastructural quality, namely IaQ4 "Patients get an adequate quantity of food in Type A Hospital" by increasing the variety of existing foods in order to increase the patient's spirit in healing.

\section{Recommendations:}

1. Develop a research model by modifying the model to get clearer results. Modifying the model needs to be done so that other variable relationships that can also affect behavioral intentions. This needs to be done in order to further clarify the important factors that can affect this variable. So that it can provide a clearer explanation for the relevant parties to be able to make better strategic steps.

2. Develop research objects in order to obtain more general research results. Especially by using research objects in other health industries to find out maximum results. In addition, research can also be done using research objects that use other industries. This needs to be done in order to obtain maximum research results for business development and knowledge in Indonesia. 


\section{REFERENCES}

Deaux, K. \& Snyder, M. (2018) “The Oxford Handbook of Personality and Social Psychology”, Oxford Library of Psychology.

Goosen, D. (2018). "Quality Infrastructure".

Gronroos, C. (1984). “A Service Quaity Model and Its Maketing Implications”. Helgeson V.S. (2003).”Social Support and Quality of Life". Research Gate.

Kotler, Philip. (2003) "Marketing Management". New Jersey: Prentice Hall.

Lemke, F., Clark, M. and Wilsom, J. (2011), "Customer experience quality: an exploration in business and consumer contexts using repertory grid technique", Journal of the Academy of Marketing Science, Vol. 39, December, pp. 846-869.

Murdoko, E. W. H. (2006). "Personal Quality Management". PT Elex Media Kumpotindo Kelompok Gramedia Jakarta

Oliver, R.L. (2010). "Satisfaction: A behavioural perspective on the customers", 2nd ed, Routledge (Taylor and Francis Group), New York, NY.

Padma, P. et. al. (2010) "Service quality and its impact on customer satisfaction in Indian hospitals". Department of Management Studies, Indian Institute of Technology Madras, Chennai, India

Sharma, N., \& Patterson , P. G. (1999). "The Impact of Communication Effectiveness and Service Quality on Relationship Commitment in Consumer, Professional Service".https:/europa.eu/capacity4dev/newtbtprogramme-new/wiki/quality-infrastructure-1

Statistik, A. S. (2016). "Uji Normalitas dengan Menggunakan SPSS". http://www.spssstatistik.com/ujinormalitas-dengan-menggunakan-spss. 17 Januari 2021

Swapnarag S \& Kar, C.N., (2018) "Hospital service quality as antecedent of patient satisfaction - a conceptual framework", International Journal of Pharmaceutical and Healthcare Marketing, https://doi.org/10.1108/IJPHM-06-2016-0028

Warshaw \& Davis. (2009). "Research Quarterly for Exercise and Sport", Vol. 80, American Alliance for Health, Physical Education, Recreation, and Dance. 